\title{
Local environment characteristics associated with walking and taking transit to shopping districts
}

\author{
Robert James Schneider \\ University of Wisconsin-Milwaukee \\ rjschnei@uwm.edu
}

\begin{abstract}
Mixed logit modeling was used to identify local environment characteristics associated with walking and taking public transit to and from shopping districts. The analysis was based on 388 intercept survey responses and local environment data from 20 San Francisco Bay Area shopping districts. This study makes methodological advances by 1) evaluating an extensive set of explanatory variables (travel time and cost, socioeconomic characteristics, attitudes, perceptions, and local environment characteristics) within the same modeling process and 2) analyzing shopping mode choice within a tour-based framework. Travel time, travel cost, and respondent socioeconomic characteristics had expected relationships with mode choice. Walking to and from shopping districts was associated with shorter trip distances (i.e., shorter travel time relative to other modes). Transit use was associated with shopping district population density and proximity to a transit station. Automobile use was discouraged by higher employment densities and smaller parking lots. The results support strategies such as developing high-density, mixed-use activity hubs; reducing surface parking; and increasing the price of on-street parking to increase walking and taking transit to shopping districts.
\end{abstract}

Keywords: Pedestrian, transit, mode choice, shopping district, mixed logit

\author{
Article history: \\ Received: November 30, 2013 \\ Received in revised form: August \\ 15, 2014 \\ Accepted: December 12, 2014 \\ Available online: June 26, 2015 \\ Data availability: http://dx.doi. \\ org/10.5198/jtlu.2015.666.s298
}

\section{Introduction}

One goal of the sustainable transportation movement is to reduce travel by private automobile and increase travel by walking, bicycling, and public transit (Litman and Burwell 2006; Schneider 2013a). These modes can provide mobility to people of all incomes and abilities, decrease reliance on fossil fuels, and use public infrastructure and space efficiently. Walking (including walking to transit) and bicycling also provide physical activity, which can reduce obesity and other chronic diseases (Besser and Dannenberg 2005, Wasfi, Ross, and El-Geneidy 2013).

Despite recent policies to support multimodal transportation in the United States (Schneider 2013a), broad modal shifts have not yet occurred. The private motor vehicle accounts for 83 percent of all trips and is the most common transportation mode used in every metropolitan region. Driving

Copyright 2015 Robert James Schneider

http://dx.doi.org/10.5198/jtlu.2015.666

ISSN: 1938-7849 | Licensed under the Creative Commons Attribution - Noncommercial License 3.0

The Journal of Transport and Land Use is the official journal of the World Society for Transport and Land Use (WSTLUR) and is published and sponsored by the University of Minnesota Center for Transportation Studies. This paper is also published with sponsorship from WSTLUR and the Institutes of Transportation Studies at the University of California, Davis, and University of California, Berkeley. 
may be even more common for routine travel purposes, such as shopping. More than one-quarter of all home-based trips are made for shopping purposes, and 89 percent of these trips are made by automobile (Federal Highway Administration 2009). In many US communities, local environment characteristics make driving a more attractive choice than walking or taking transit.

Travel behavior research has shown that mode choice is influenced by travel, socioeconomic, local environment, and attitude and perception variables. Some of these variables can be changed through planning, design, and engineering strategies to encourage walking and transit use. However, relatively few studies have attempted to account for all of these types of variables simultaneously, potentially reducing the accuracy of findings that identify local environment variables associated with sustainable transportation. This study uses survey data from the San Francisco Bay Area to explore the following research question: After controlling for other influences on travel behavior, what local environment characteristics are associated with walking and taking transit to and from shopping districts?

\section{$2 \quad$ Literature review}

Researchers have identified many variables associated with pedestrian and public transit mode choices. Walking is generally slower than driving or taking transit, so shorter travel time and distance are travel characteristics that tend to be associated with a higher likelihood of walking (Purvis 1997, Steiner 1998, Bowman and Ben-Akiva 2000, Jonnalagadda et al. 2001, Cervero and Duncan 2003). Shorter travel times (e.g., travel to the transit stop, wait time, transfer time, and in-vehicle travel time) and distances to transit stops also support public transit (Evans 2004, Cantwell, Caulfield, and O'Mahony, 2009, Ewing and Cervero 2010, Redman et al. 2013). Expensive gas, expensive automobile parking, and limited automobile parking availability may also increase the relative attractiveness of walking and transit (Shoup 1997, Black, Collins, and Snell 2001, Vaca and Kuzmyak 2005, Ryley 2008, Rodriguez et al. 2008, Krizek, Forsyth, and Baum 2009).

Barriers to walking include traveling with another person (Kim and Ulfarsson 2008), carrying heavy packages (Mackett 2003), hills (Cervero and Duncan 2003, Schneider et al. 2012), rain (Cervero and Duncan 2003), and darkness (Cervero and Duncan 2003). Barriers to transit include high fares (Eboli and Mazzulla 2008, Redman et al. 2013), limited route coverage (Pratt and Evans 2004), inadequate information about routes and schedules (Too and Earl 2010), discomfort of standing or sitting in the bus (Redman et al. 2013), inability to use travel time productively (Rubin 2011), crowding (Cantwell et al. 2009), and uncleanness (Eboli and Mazzulla 2008).

Automobile ownership and availability are negatively associated with walking and public transit (Bowman and Ben-Akiva 2000, Cervero and Duncan 2003, Kim and Ulfarsson 2008, Redman et al. 2013). People with pro-environment attitudes and people who say they enjoy walking tend to walk more than the general population (Kitamura, Mokhtarian, and Laidet 1997, Handy, Cao, and Mokhtarian 2005, Manaugh and El-Geneidy 2013). People who perceive traffic safety risk and crime risk are less likely to walk (Saelens et al. 2003, Suminski et al. 2005, Schneider 2013a), and people who think that crime occurs frequently on transit are less likely to take transit (Rubin 2011).

Walking and public transit are more common in areas with higher population and employment densities and greater land use mix (Purvis 1997, Cervero and Duncan 2003, Ewing and Cervero 2010). Short distances between activity locations are particularly important for walking (Krizek, Forsyth, and Baum 2009, Schneider, Arnold, and Ragland 2009). Transportation infrastructure, such as sidewalks, multi-use trails, street network connectivity, and intersection density (i.e., more direct route options), tend to be positively associated with walking (Jonnalagada et al. 2001, Cervero and Duncan 2003, Ewing and Cervero 2010).

To evaluate the choices of walking and taking transit versus driving, it is essential to understand 
when modes are chosen. Some studies have explored the choice of mode for individual trips between two activity locations (Purvis 1997, Cervero and Duncan 2003, Kim and Ulfarsson 2008, Ryley 2008). However, the choice whether or not to take a car for all trips in a single tour (i.e., trip-chain) is often made before leaving home. Krizek (2003) and Chen, Gong, and Paaswell (2008) suggest that mode choice should be analyzed for tours (rather than individual trips). Surprisingly, there are few tour-based studies of walking and transit mode choice (Bowman and Ben-Akiva 2000, Jonnalagada et al. 2001, Frank et al. 2008).

This review identifies a need to control for more categories of explanatory variables, including travel, socioeconomic, attitude and perception characteristics, in order to identify significant local environment variables related to pedestrian and transit mode choice. In addition, more studies should consider mode choice at the tour level rather than the trip level.

\section{Survey data}

Detailed travel data were gathered from an intercept survey of retail pharmacy store customers in 20 San Francisco Bay Area shopping districts (Schneider 2013b). Survey stores were selected from the same national retail pharmacy chain. Retail pharmacies were chosen over other types of stores because they were assumed to have customers using a greater variety of travel modes (i.e., they tend to have smaller trade areas and smaller purchases, so they are less likely to be dominated by automobile customers). Shopping districts were defined as the area within an 804-meter (0.5-mile) radius of the retail pharmacy store where the survey was administered. Four general types of shopping districts were identified using cluster analysis (Table 1). More details on the selection of store type, selection of shopping districts, and cluster analysis are provided in a summary report (Schneider 2011). 
Table 1: General types of shopping districts studied

\begin{tabular}{|c|c|c|c|c|}
\hline & $\begin{array}{l}\text { Urban Core } \\
\text { (3 districts) }\end{array}$ & $\begin{array}{c}\text { Suburban Main Street } \\
\text { (8 districts) }\end{array}$ & $\begin{array}{c}\text { Suburban Thoroughfare } \\
\text { (7 districts) }\end{array}$ & $\begin{array}{c}\text { Suburban Shopping } \\
\text { Center ( } 2 \text { districts) }\end{array}$ \\
\hline General description & $\begin{array}{l}\text { High density with } \\
\text { mixed-use buildings } \\
\text { (retail, residential, } \\
\text { office). Buildings with } \\
2 \text { to } 20 \text { stories and } \\
\text { short setbacks. Served } \\
\text { by high-frequency } \\
\text { transit. Short building } \\
\text { setbacks. Slow-speed } \\
\text { traffic on 2- to 4-lane } \\
\text { streets. Limited } \\
\text { automobile parking } \\
\text { provided on-street and } \\
\text { in parking structures. }\end{array}$ & $\begin{array}{l}\text { Moderate density } \\
\text { with some single-use } \\
\text { and some mixed-use } \\
\text { buildings. Buildings } \\
\text { with } 1 \text { to } 3 \text { stories and } \\
\text { short setbacks. Served } \\
\text { by moderate-frequency } \\
\text { transit. Slow-speed } \\
\text { traffic on 2-lane streets. } \\
\text { Some metered and } \\
\text { some free on-street } \\
\text { parking. Minimal } \\
\text { off-street parking other } \\
\text { than public parking lots } \\
\text { or structures. }\end{array}$ & $\begin{array}{l}\text { Low density with single- } \\
\text { use buildings. Moderate- } \\
\text { sized, 1-story buildings } \\
\text { set back from the road- } \\
\text { way behind moderate- } \\
\text { sized parking lots. Most } \\
\text { stores have their own } \\
\text { parking lots. High-speed } \\
\text { traffic on 4- to 6-lane } \\
\text { thoroughfares. Minimal } \\
\text { on-street parking and } \\
\text { many commercial drive- } \\
\text { way crossings. }\end{array}$ & $\begin{array}{l}\text { Low density with } \\
\text { single-use buildings. } \\
\text { Large, 1-story build- } \\
\text { ings set back from the } \\
\text { roadway behind large } \\
\text { parking lots. Extensive } \\
\text { parking lot space is } \\
\text { shared among stores. } \\
\text { High-speed traffic on } \\
\text { 4- to 6-lane thorough- } \\
\text { fares. Minimal on-street } \\
\text { parking and a moderate } \\
\text { number of commercial } \\
\text { driveway crossings. }\end{array}$ \\
\hline \multicolumn{5}{|c|}{ Variables Used to Classify Types of Shopping Districts ${ }^{1}$} \\
\hline $\begin{array}{l}\text { Population per sq. } \\
\text { km. }^{2}\end{array}$ & $\begin{array}{l}10,900 \text { to } 15,900 \\
(\text { Mean }=12,900)\end{array}$ & $\begin{array}{l}2200 \text { to } 6300 \\
(\text { Mean }=5400)\end{array}$ & $\begin{array}{l}800 \text { to } 3200 \\
(\text { Mean }=2200)\end{array}$ & $\begin{array}{l}1900 \text { to } 4300 \\
(\text { Mean }=3100)\end{array}$ \\
\hline $\begin{array}{l}\text { Employment per sq. } \\
\mathbf{k m}^{3}\end{array}$ & $\begin{array}{l}3700 \text { to } 71,500 \\
(\text { Mean }=27,500)\end{array}$ & $\begin{array}{l}800 \text { to } 3100 \\
(\text { Mean }=1800)\end{array}$ & $\begin{array}{l}100 \text { to } 5700 \\
(\text { Mean }=1700)\end{array}$ & $\begin{array}{l}400 \text { to } 600 \\
(\text { Mean }=500)\end{array}$ \\
\hline Sidewalk coverage ${ }^{4}$ & $\begin{array}{l}100 \% \text { to } 100 \% \\
(\text { Mean }=100 \%)\end{array}$ & $\begin{array}{l}77 \% \text { to } 100 \% \\
(\text { Mean }=92 \%)\end{array}$ & $\begin{array}{l}74 \% \text { to } 100 \% \\
(\text { Mean }=90 \%)\end{array}$ & $\begin{array}{l}54 \% \text { to } 84 \% \\
(\text { Mean }=69 \%)\end{array}$ \\
\hline $\begin{array}{l}\text { Lanes on main } \\
\text { shopping street }^{5}\end{array}$ & $\begin{array}{l}2.0 \text { to } 4.0 \\
(\text { Mean }=3.3)\end{array}$ & $\begin{array}{l}2.2 \text { to } 4.0 \\
(\text { Mean }=3.3)\end{array}$ & $\begin{array}{l}.0 \text { to } 6.0 \\
(\text { Mean }=5.0)\end{array}$ & $\begin{array}{l}4.5 \text { to } 4.9 \\
(\text { Mean }=4.7)\end{array}$ \\
\hline $\begin{array}{l}\text { Driveway crossings } \\
\text { per } \mathbf{k m} .^{6}\end{array}$ & $\begin{array}{l}0.0 \text { to } 0.0 \\
(\text { Mean }=0.0)\end{array}$ & $\begin{array}{l}1.2 \text { to } 21.5 \\
(\text { Mean }=11.8)\end{array}$ & $\begin{array}{l}8.9 \text { to } 44.8 \\
(\text { Mean }=25.3)\end{array}$ & $\begin{array}{l}9.5 \text { to } 11.5 \\
(\text { Mean }=10.5)\end{array}$ \\
\hline $\begin{array}{l}\text { Parking spaces at } \\
\text { store }^{7}\end{array}$ & $\begin{array}{l}0 \text { to } 10 \\
(\text { Mean }=3)\end{array}$ & $\begin{array}{l}0 \text { to } 310 \\
(\text { Mean }=75)\end{array}$ & $\begin{array}{l}44 \text { to } 290 \\
(\text { Mean }=160)\end{array}$ & $\begin{array}{l}420 \text { to } 442 \\
(\text { Mean }=431)\end{array}$ \\
\hline
\end{tabular}

1) Cluster analysis was based on the six variables listed in the table. Since the cluster analysis considered all six variables, the range of values for each individual variable overlapped between certain types of shopping districts.

2) Population density was calculated for the area within 0.5 miles (804 meters) of the survey store. Source: US Census (2000).

3) Employment density was calculated for the area within 0.5 miles ( 804 meters) of the survey store. Source: San Francisco Bay Area Metropolitan Transportation Commission traffic analysis zones (2005).

4) The sidewalk coverage calculation assumed complete coverage was continuous sidewalks on both sides of the street. If a street had sidewalks on both sides, it had 100 percent sidewalk coverage. If a street had a complete sidewalk on one side, but no sidewalk on the other, it had 50 percent coverage. Source: Google Earth and Bing Maps aerial photographs (2007-2009).

5) Travel lanes included all general-purpose through-lanes in both directions, averaged by block. The number of through-lanes did not include left- or right-turn lanes, two-way center-turn lanes, bicycle lanes, shoulders, or other auxiliary lanes. In addition, it did not include lanes that ended within the block. Source: Google Earth and Bing Maps aerial photographs (2007-2009).

6) Major driveway crossings included all active non-residential and more than 10-unit residential property driveways. Source: Google Earth and Bing Maps aerial photographs (2007-2009).

7) Number of spaces in the survey store parking lot included shared parking with other stores in the same shopping complex. Source: Google Earth and Bing Maps aerial photographs (2007-2009). 
The surveys were administered in-person by the lead researcher and two Spanish-speaking assistants between August 29, 2009, and December 9, 2009. Of the 4585 customers invited to participate, 1003 (22 percent) took the survey. The participants were similar to people who were invited to take the survey but declined to participate in terms of gender, age, and group size, so there was little evidence of these types of non-response biases. Other types of non-response bias may have occurred, such as lower response rates from lower-income customers or customers who were time constrained. The researchers read the questions verbally and recorded responses while standing next to individual participants, allowing them to see that their answers were recorded correctly. Approximately half of the surveys at each store were done on weekday afternoons (excluding Fridays) between 4 p.m. and 6 p.m., and half were done on Saturdays between $11 \mathrm{a} . \mathrm{m}$. and 5 p.m. All surveys were administered during daylight and fair weather conditions. Temperatures during survey periods ranged from $10^{\circ} \mathrm{C}\left(50^{\circ} \mathrm{F}\right)$ to $29^{\circ} \mathrm{C}\left(85^{\circ} \mathrm{F}\right)$. Surveys were not offered when it was raining or when the previous day's forecast predicted more than a 50 percent chance of rain.

Participants reported socioeconomic characteristics, attitudes toward different travel modes, perceptions of crash and crime risk within the shopping district, and the locations of their homes and all stops that they made and planned to make before returning home. They also reported all modes of transportation that they used to travel between each activity location, including movements within the shopping district. Additional detail about the survey process is provided in a summary report (Schneider 2011).

\subsection{Shopping district tours versus multi-district tours}

Of all participants, 959 (96 percent) provided complete tour data (i.e., reported the location of their home and all stops on their tour). Of these 959 participants, 397 (41 percent) made all of their nonhome stops within the shopping district around the retail pharmacy store (i.e., made simple homeshopping district-home tours). These 397 respondents were the subject of further mode choice analysis. The other 562 respondents were excluded to eliminate broader tour influences on shopping district mode choice. These 562 respondents tended to travel longer distances, make more stops, and decided to go to the retail pharmacy store after they had already left home (Table 2). The mode used by many these respondents to access the shopping district may have been influenced by other activity locations and trip purposes on their broader tours, so it was less likely to represent the true association between mode choice and shopping district characteristics.

Constraining the analysis to respondents who made all of their tour stops within the same shopping district created a sample with a higher proportion of survey responses from shopping districts with

a greater concentration of activities. However, the dataset still included respondents from all types of districts (Table 3), and activity density variables (i.e., population density, employment density, and commercial property density) were used to control for this potential bias in the modeling process. 
Table 2: Comparison of tour characteristics

\begin{tabular}{|c|c|c|}
\hline Travel Characteristics & $\begin{array}{r}\text { All Stops Within Shopping } \\
\text { District }(\mathrm{n}=397)\end{array}$ & $\begin{array}{r}\text { At least } 1 \text { Stop Outside Shopping } \\
\text { District }(n=562)\end{array}$ \\
\hline Mean Tour Distance $(\mathrm{km})$ & 6.3 & 29.4 \\
\hline Median Tour Distance (km) & 2.7 & 15.4 \\
\hline Mean \# of Stops ${ }^{1}$ & 3.3 & 4.9 \\
\hline Median \# of Stops ${ }^{1}$ & 3.0 & 4.0 \\
\hline Carrying No Bags & $16.4 \%$ & $14.1 \%$ \\
\hline Carrying 2+ Bags & $24.7 \%$ & $24.2 \%$ \\
\hline Shopping Alone & $74.4 \%$ & $73.8 \%$ \\
\hline Shopping on Saturday & $51.6 \%$ & $48.6 \%$ \\
\hline $\begin{array}{l}\text { Planning Characteristics } \\
\text { (when decided to go to store) }\end{array}$ & $\begin{array}{r}\text { All Stops Within Shopping } \\
\text { District }(\mathrm{n}=397)\end{array}$ & $\begin{array}{r}\text { At least } 1 \text { Stop outside Shopping } \\
\text { District }(n=562)\end{array}$ \\
\hline Decided yesterday or before & $16.4 \%$ & $23.2 \%$ \\
\hline Decided before leaving home & $55.8 \%$ & $31.7 \%$ \\
\hline Decided after leaving home & $16.4 \%$ & $28.9 \%$ \\
\hline Decided passing by store & $11.4 \%$ & $16.2 \%$ \\
\hline $\begin{array}{l}\text { Primary Mode Used on Tour } \\
\text { (greatest distance) }\end{array}$ & $\begin{array}{r}\text { All Stops Within Shopping } \\
\text { District }(\mathrm{n}=397)\end{array}$ & $\begin{array}{r}\text { At least } 1 \text { Stop outside Shopping } \\
\text { District }(\mathrm{n}=562)\end{array}$ \\
\hline Walk & $42.6 \%$ & $6.2 \%$ \\
\hline Bicycle & $2.3 \%$ & $2.1 \%$ \\
\hline Transit & $6.8 \%$ & $12.1 \%$ \\
\hline Automobile & $48.4 \%$ & $79.5 \%$ \\
\hline
\end{tabular}

1) Stops include all non-home activity locations on the respondent's tour plus returning to home (i.e., total stops $=$ non-home stops +1$)$. 
Table 3: Mode share by shopping district type

(Table only includes respondents who made all tour stops within the shopping district.)

\begin{tabular}{|c|c|c|c|c|c|}
\hline 1. Urban Core & \multicolumn{5}{|c|}{ Respondent Mode Share $^{1}$} \\
\hline Shopping District & $n$ & Walk & Bicycle & Transit & Automobile \\
\hline SF-Market St. & 25 & $56 \%$ & $4 \%$ & $36 \%$ & $4 \%$ \\
\hline SF-Fillmore St. & 34 & $82 \%$ & $0 \%$ & $6 \%$ & $12 \%$ \\
\hline SF-Mission St. & 24 & $67 \%$ & $0 \%$ & $29 \%$ & $4 \%$ \\
\hline Cluster Average & 83 & $70 \%$ & $1 \%$ & $22 \%$ & $7 \%$ \\
\hline \multicolumn{6}{|l|}{ Urban core median tour distance $=2.4 \mathrm{~km}$} \\
\hline 2. Suburban Main Street & \multicolumn{5}{|c|}{ Respondent Mode Share $^{1}$} \\
\hline Shopping District & $n$ & Walk & Bicycle & Transit & Automobile \\
\hline Berkeley & 17 & $65 \%$ & $12 \%$ & $0 \%$ & $24 \%$ \\
\hline Oakland & 21 & $43 \%$ & $0 \%$ & $0 \%$ & $57 \%$ \\
\hline Richmond & 26 & $39 \%$ & $0 \%$ & $8 \%$ & $54 \%$ \\
\hline SF-Taraval St. & 20 & $55 \%$ & $0 \%$ & $5 \%$ & $40 \%$ \\
\hline SF-Third St. & 17 & $47 \%$ & $0 \%$ & $24 \%$ & $29 \%$ \\
\hline Daly City & 18 & $50 \%$ & $0 \%$ & $11 \%$ & $39 \%$ \\
\hline Burlingame & 27 & $48 \%$ & $7 \%$ & $0 \%$ & $44 \%$ \\
\hline San Mateo & 28 & $43 \%$ & $0 \%$ & $0 \%$ & $57 \%$ \\
\hline Cluster Average & 174 & $48 \%$ & $2 \%$ & $5 \%$ & $45 \%$ \\
\hline \multicolumn{6}{|c|}{ Suburban main street median tour distance $=2.2 \mathrm{~km}$} \\
\hline 3. Suburban Thoroughfare & \multicolumn{5}{|c|}{ Respondent Mode Share ${ }^{1}$} \\
\hline Shopping District & $n$ & Walk & Bicycle & Transit & Automobile \\
\hline Hayward & 19 & $21 \%$ & $0 \%$ & $0 \%$ & $79 \%$ \\
\hline Fremont & 24 & $29 \%$ & $0 \%$ & $4 \%$ & $67 \%$ \\
\hline Danville & 11 & $0 \%$ & $0 \%$ & $0 \%$ & $100 \%$ \\
\hline Brentwood & 13 & $8 \%$ & $15 \%$ & $0 \%$ & $77 \%$ \\
\hline Concord & 20 & $40 \%$ & $0 \%$ & $0 \%$ & $60 \%$ \\
\hline El Cerrito & 8 & $25 \%$ & $0 \%$ & $0 \%$ & $75 \%$ \\
\hline San Carlos & 16 & $0 \%$ & $13 \%$ & $6 \%$ & $81 \%$ \\
\hline Cluster Average & 111 & $20 \%$ & $4 \%$ & $2 \%$ & $75 \%$ \\
\hline \multicolumn{6}{|c|}{ Suburban thoroughfare median tour distance $=4.6 \mathrm{~km}$} \\
\hline 4. Suburban Shopping Center & \multicolumn{5}{|c|}{ Respondent Mode Share $^{1}$} \\
\hline Shopping District & $n$ & Walk & Bicycle & Transit & Automobile \\
\hline Pleasanton & 14 & $14 \%$ & $0 \%$ & $0 \%$ & $86 \%$ \\
\hline South San Francisco & 15 & $13 \%$ & $0 \%$ & $0 \%$ & $87 \%$ \\
\hline Cluster Average & 29 & $14 \%$ & $0 \%$ & $0 \%$ & $86 \%$ \\
\hline \multicolumn{6}{|c|}{ Suburban shopping center median tour distance $=3.3 \mathrm{~km}$} \\
\hline \multirow[t]{2}{*}{ Overall } & \multicolumn{5}{|c|}{ Respondent Mode Share ${ }^{1}$} \\
\hline & $n$ & Walk & Bicycle & Transit & Automobile \\
\hline Overall Average & 397 & $42 \%$ & $2 \%$ & $7 \%$ & $48 \%$ \\
\hline
\end{tabular}

1) Survey respondent transportation mode share is the mode that the person used for the greatest distance on the portion of their tour where they were traveling in either direction between their home and the survey shopping district. Only respondents who made all of their stops within the shopping district were considered in this analysis. Cluster average is the weighted average of individual store data based on surveys per store (2009). 


\subsection{Respondent characteristics}

Of the 397 participants who made all of their tour stops within the same shopping district, 55 percent were female, 52 percent were aged 35 to 64,16 percent were 65 or older, 74 percent traveled alone, and 10 percent took the survey in Spanish. This subset had slightly higher shares of male and senior citizen respondents than the full set of 1003 respondents.

\subsection{Mode choice by type of shopping district}

Overall, 192 (48 percent) of the 397 respondents used an automobile (including drivers and passengers) as their primary travel mode, while 167 (42 percent) walked, 29 (7 percent) took transit, and 9 (2 percent) bicycled. There were considerable differences in respondent mode choice by type of shopping district (Table 3). Most customers traveling to and from San Francisco urban core shopping districts walked or took transit, while most customers traveling to suburban thoroughfare and suburban shopping center shopping districts used an automobile.

\section{$4 \quad$ Statistical modeling}

Discrete choice modeling is a common approach for identifying variables that are associated with mode choices (Bowman and Ben-Akiva 2000, Jonnalagada et al. 2001, Cervero and Duncan 2003, Kim and Ulfarsson 2008, Ryley 2008). Mixed logit models have analyzed various types of automobile, public transit, and air transportation choices (Viton 2004, Long, Lin, and Proussaloglou 2010), but few have evaluated pedestrian mode choice. The mixed logit structure has flexibility to account for multi-level data, such as groups of surveys collected at several different stores (Train 2009).

A series of mixed logit models were developed to test for associations between more than $60 \mathrm{ex}-$ planatory variables and respondent mode choices. Explanatory variables included travel, socioeconomic, attitude, perception, and shopping district characteristics (Appendix A). These variables were derived from responses to the intercept survey, aerial photographs, Census data, and field observations.

Since there were only nine survey participants who bicycled to and from shopping districts, the bicycle mode was not included in the modeling process. The mixed logit models used the remaining 388 responses.

\subsection{Model structure}

The mixed logit models assumed that each customer $\mathrm{n}$ of the $\mathrm{N}=388$ respondents chose the mode $\mathrm{i}$ of the $\mathrm{I}=$ three alternatives that maximized his or her utility. Each respondent was surveyed at store q of the $\mathrm{Q}=20$ stores, so the model was also structured to capture similarities between the modes chosen by individuals at each store. This multi-level data structure had been developed previously for a mixed logit model (Bhat and Gossen 2004).

The utility of a respondent $\mathrm{n}$ choosing each mode $(\mathrm{i}=1,2$, or 3$)$ to travel to and from a particular shopping district containing store $\mathrm{q}$ was expressed in the following equations:

$$
\begin{aligned}
& U_{q 1 n}=\alpha_{1}+\beta_{1} X_{q 1 n}+\gamma_{1} v_{q 1}+\mu_{12} \eta_{q n}+\varepsilon_{q 1 n} \\
& U_{q 2 n}=\alpha_{2}+\beta_{2} X_{q 1 n}+\gamma_{2} v_{q 2}+\mu_{12} \eta_{q n}+\varepsilon_{q 2 n} \\
& U_{q 3 n}=\alpha_{3}+\beta_{3} X_{q 1 n}+\gamma_{3} v_{q 3}++\varepsilon_{q 3 n}
\end{aligned}
$$


Where:

- $\alpha_{i}$ are mode-specific constants.

- $X_{\text {qin }}$ are column vectors of explanatory variables (travel, socioeconomic, attitude, perception, and shopping district variables). Certain variables are generic (e.g., used in the column vectors for all modes), while other variables are mode-specific (e.g., only used in the column vector for one mode).

- $\beta$ are row vectors of coefficients that quantify the relationship between each known variable and the observed utility of choosing each mode $i$.

- $v_{q 1}, v_{q 2}$, and $v_{q 3}$ are variables representing the unobserved correlated error between people who used mode 1,2, or 3 and took the survey at the same store. These variables are assumed to be distributed independently identically normal across stores but constant across individuals from the same store. It is possible that respondents at the same store had similar preferences that are not captured by the known variables, so it is important to control for this effect in the model.

- $\gamma_{i}$ are coefficients that quantify the variance of the store-level error for each mode i.

- $\eta_{a n}$ is a variable that represents the unobserved correlated error between mode 1 and mode 2 . This accounts for potential interdependence between the choice of mode 1 and mode 2 . This variable is assumed to be distributed independently identically normal across stores but constant across individuals who use the same store.

- $\mu_{12}$ is a parameter that quantifies the covariance of the error between modes 1 and 2 . This covariance parameter is analogous to a nesting coefficient in a nested logit model. During the modeling process, covariance parameters were also estimated to test for interdependence between modes 1 and 3 and between modes 2 and 3 .

- $\varepsilon_{\text {qin }}$ are unobserved error terms. These errors are assumed to be independently and identically distributed type 1 extreme value across individuals.

The unconditional probability of customers selecting walking, transit, or driving and the unconditional likelihood function for the sample of respondents are detailed in the summary report (Schneider 2011). BIOGEME software was used to estimate the model parameters of $\alpha, \beta, \gamma$, and $\mu$ (Bierlaire 2003). Variables that showed consistent statistical associations with mode choice across the series of models were included in the final model.

\subsection{Final model}

The final mixed logit model included 27 parameters corresponding with 22 variables and a constant (a dummy variable accounting for unreported income is not shown in the table). Overall, the model loglikelihood (-154) was relatively high compared with the log-likelihood value for no model (-376) and the log-likelihood value of a model with only constants (-292). Its adjusted rho-squared value was 0.518 (Table 4). The model predicted the mode chosen by 322 ( 83 percent) of the 388 survey participants correctly.

Parameter estimates were provided for theoretically important explanatory variables with p-values $<0.30$. However, parameters were considered to be highly significant for $\mathrm{p}<0.01$ and significant for $0.01<\mathrm{p}<0.05$. A likelihood ratio test showed that the final model with seven attitude, perception, and shopping district variables had more explanatory power than a restricted model with only travel and socioeconomic variables (99 percent confidence level).

The multi-level error structure accounted for unmeasured characteristics that were shared between survey participants in each of the 20 shopping districts. The multi-level parameter for automobile was significant, suggesting that the other model variables may not have captured all shopping district char- 
acteristics related to automobile mode choice, such as parking availability and traffic congestion during survey periods. Note that other models were estimated with combinations of just two of the three multi-level variables, but these models had similar parameter estimates as the final model, so they are not presented.

Several model alternatives were tested with nesting parameters between two of the three modes. Walking was nested with transit in the first alternative, walking was nested with automobile in the second, and transit was nested with automobile in the third. However, none of these combinations were significant, so no nesting parameter was included in the final model. 
Table 4.1: Variables associated with shopping district tour mode choice

Mixed logit model for survey respondents traveling only to and from shopping district ${ }^{1}$

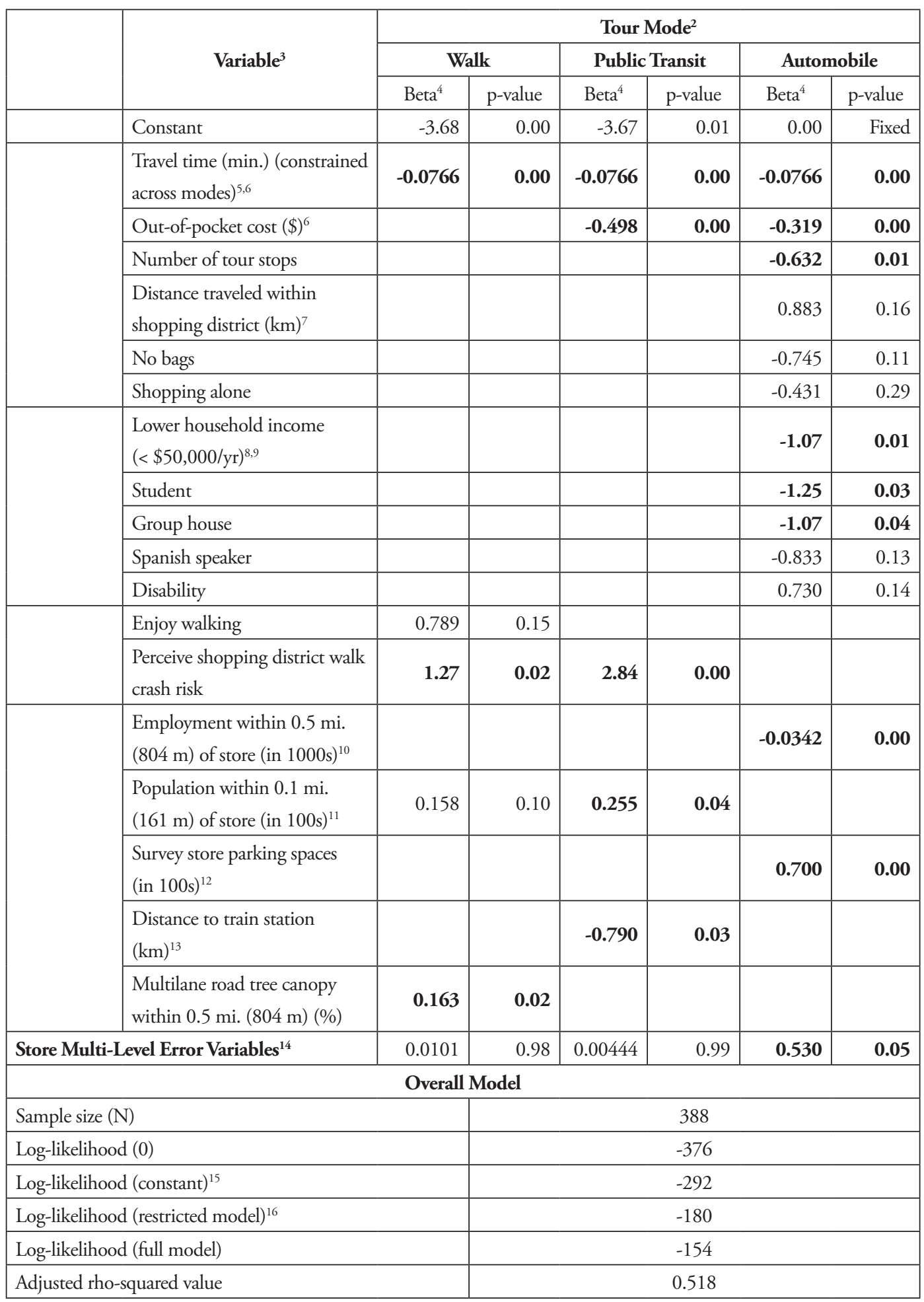


Table 4.2: Variables associated with shopping district tour mode choice: Footnotes

1) The dependent variable in the model is the primary (greatest distance) mode of transportation used to travel to and from the retail pharmacy store area for tours that had all non-home stops within 0.5 miles (804 meters) of the retail pharmacy store. The mode used for the 388 survey respondents was: Automobile $=192$ (49.5 percent), Walk = 167 (43.0 percent), Transit $=29$ (7.5 percent). Nine respondents who traveled by bicycle were removed from this model analysis. Parameter estimates were generated after 1000 draws. They were verified as stable from 500 to 1000 draws.

2) The automobile mode includes driving and riding as a passenger in a motorized vehicle other than a public bus or train (taxi is included within automobile mode). The walk mode includes all pedestrians, including people on foot, in wheelchairs, and using other assistive devices. The public transit mode includes bus, regional rail, light rail, commuter train, other train, and paratransit. 3) Several other variables were expected to have significant associations with respondent mode choice and were tested during the modeling process. These variables were taking the survey on Saturday, being female, living in a no-child household, being able to change modes easily, perceiving negative bicycle culture, perceiving a risk of crime when walking in the shopping district, number of commercial properties within 0.25 miles (402 meters) of the survey store, slope of multilane roads in the shopping district, number of intersections in the shopping district, and drive-through pharmacy window at the survey store. However, their parameter estimates were imprecise $(\mathrm{p}>0.30)$ and had minimal influence on other parameters, so they were not included in the final model.

4) Parameter estimates (beta values) represent coefficients in the utility function for choosing each transportation mode. The base mode for each variable is the mode with no parameter estimate.

5) Travel time was estimated as a generic parameter that was the same for all modes.

6) Out-of-pocket cost and travel time parameters were used to calculate the value of time at $\$ 9.23 / \mathrm{hr}$. for transit users and $\$ 14.41 /$ hr. for automobile users.

7) Travel distance within the shopping district is the distance the respondent traveled between his or her first stop within 0.5 miles (804 meters) of the retail pharmacy store and his or her final stop within 0.5 miles (804 meters) of the retail pharmacy store in miles.

8) 41 of the 388 respondents did not report their income category, so a dummy variable was estimated to account for missing values. The parameter for variable was included in the automobile utility equation, and it had a parameter estimate of 0.251 and p-value of 0.66 .

9) The low-household-income variable was positively correlated with not owning an automobile. A variable representing respondents with no household automobiles was tested in place of the low-income variable, but its parameter estimate was less precise and the overall model fit was not as good.

10) Employment within 0.5 miles ( 804 meters) of the store is the total number of jobs within this area (it is not a direct measure of density).

11) Population within 0.1 miles (161 meters) of store is the total number of people within this area (it is not a direct measure of density).

12) Survey store automobile parking spaces include all spaces in the entire parking lot if it is shared with other stores.

13) Distance from store to closest Bay Area Rapid Transit or other heavy rail train station was measured as the straight-line distance from the store centroid to the train station centroid.

14) The store multi-level variable parameters capture the correlated error between respondents who were surveyed at the same store. Approximately 50 customers were surveyed at each store (and approximately 20 respondents at each store were used in this analysis), so they share identical shopping district variables and may have similar socioeconomic or attitude characteristics.

15) Log-likelihood (constant) is the log-likelihood of a constants-only model that includes the multi-level variables.

16) Log-likelihood (restricted model) is the log-likelihood of a model without the attitude and perception and shopping district variables. 


\section{$5 \quad$ Results}

To identify local environment characteristics associated with walking and taking transit to shopping districts, it was important to control for many possible influences on mode choice.

\subsection{Travel characteristics}

Longer travel times were associated with lower utilities for walking, taking transit, and driving. Walking was typically the slowest mode, so the attractiveness of walking was substantially lower than taking transit or driving for people who lived far from the shopping district. However, walking was competitive with driving for very short distances (generally less than 0.25 miles, or 402 meters) between the respondent's home and the retail pharmacy store (driving time included time to find a parking spot and walk to the door of a store).

Estimated out-of-pocket travel cost was evaluated for both public transit and automobile modes, and it showed that customers were less likely to use these modes when they were more expensive. The value of time calculated from the model for transit users was $\$ 9.23$ per hour, and for automobile drivers it was $\$ 14.41$ per hour. This is in the same range as the value of time calculated from the 1990 Bay Area Travel Survey, which was $\$ 15.96$ per hour for work trips and $\$ 10.88$ per hour for shopping trips (adjusted to 2009 dollars) (Purvis 1997).

Respondents who made more stops on their tours were more likely to have walked or taken transit than to have traveled by automobile to the shopping district. Previous research suggested that the number of tour stops was negatively associated with walking (Jonnalagada et al. 2001) and transit (Hensher and Reyes 2000). However, the negative association between the number of tour stops and choosing automobile suggested that pedestrians and transit users may take advantage of stores that are clustered within a shopping district (clustered stores were more common in urban core and suburban main street shopping districts).

The distance that survey respondents traveled within the shopping district was expected to have a positive association with traveling by automobile to and from the shopping district. This is because it is often more convenient for a person to have a car available to drive between widely distributed stops within a shopping district. Carrying bags and shopping in groups were also expected to be positively associated with driving to and from shopping districts. While the parameters for these variables had the expected signs, they were not statistically significant.

\subsection{Socioeconomic characteristics}

Respondents were significantly more likely to walk and take transit than to drive to the shopping district if they had a lower household income, were students, or lived in a group house. Variables indicating that the respondent took the survey in Spanish and had a physical disability were not statistically significant.

\subsection{Attitude and perception characteristics}

Respondents' enjoyment of walking was included in the model to account for one aspect of neighborhood self-selection. For example, people who enjoy walking may choose to live in places where they can walk to the local shopping district. Not measuring this preference could lead to overestimating the influence of built environment characteristics on mode choice (Handy, Cao, and Mokhtarian 2005, Cao, Mokhtarian, and Handy 2009). However, research also suggests that many other factors besides travel preferences influence where people live and that some people may not actually be able to find a neigh- 
borhood that matches their travel preferences. As a result, self-selection bias may lead to either overestimating or underestimating the influence of built environment variables on travel behavior (Chatman 2009). Enjoyment of walking was included in the model, but it did not have a statistically significant relationship with the choice to walk to shopping districts.

There was a significant positive association between the perceived risk of pedestrian crashes in the shopping district and walking and taking transit to the shopping district. This result may seem counterintuitive, but it could be due to pedestrians and transit users being more familiar with risks such as speeding traffic and drivers not yielding to pedestrians in crosswalks than automobile users.

\subsection{Shopping district characteristics}

Shopping district employment density was negatively associated with automobile mode choice. Since travel time was already included in the model, employment density did not simply reflect more walking (and less driving) due to people working close to shopping opportunities. Employment density may capture the effect of roadways with higher levels of traffic congestion, a high demand for automobile parking, and limited space for automobile parking. All of these factors could decrease the utility of driving relative to other modes. In addition, areas with high employment densities often have a higher density of transit stops and more frequent transit service than other areas.

Population density near the retail pharmacy store where the survey was administered was positively associated with transit use. This may be due to higher-density areas having less convenient automobile access (e.g., more traffic congestion, less available parking) and better transit service than lower-density areas. Proximity to a regional train station also increased the likelihood of taking transit to the shopping district.

The number of off-street automobile parking spaces at the retail pharmacy survey store had a significant positive relationship with automobile mode choice. Shopping districts with many large parking lots also tended to have lower employment densities, lower population densities, and respondents living farther from the shopping district. This combination of characteristics favored automobile access to the shopping district.

Tree canopy coverage along multilane roadways had a significant positive relationship with the utility of walking. Street trees may increase shade and make walking a more enjoyable experience. However, additional testing is needed to determine if tree canopy is a proxy for other local environment variables, such as neighborhood age (i.e., shopping districts with larger street trees may be older and have more walkable development patterns).

The final model suggested that five specific shopping district variables (i.e., population density, employment density, distance to a transit station, number of parking spaces at the survey store, and multilane tree canopy) were significantly associated with shopping district mode choice, but several other models were estimated to explore the possibility that mode choice could simply be predicted by the general type of shopping district being accessed. The simplest of these alternatives used shopping district dummy variables (e.g., suburban main street, suburban thoroughfare) in place of the five specific shopping district variables. However, this model did not perform as well as the final model (lower adjusted-rho-squared value). The shopping district dummy variables were good proxies for population and employment density, but they did not capture the influence of all five specific shopping district variables. A likelihood ratio test showed that adding the variables distance to transit station and survey store parking spaces to the shopping district dummy variables significantly increased the explanatory power of those models ( 95 percent confidence level). Exploring these alternatives suggested that the final model shown in Table 4 was preferred.

Other shopping district environment variables may also be associated with shopping district mode 
choices, but their individual impacts were difficult to isolate. For example, shopping districts with higher on-street parking costs tended to have more concentrated retail stores and higher employment densities. The combination of these characteristics may make driving relatively more expensive and less convenient than other modes. However, the variables representing these characteristics were correlated, so only one was included in the final model (employment density was included because it produced the best overall fit).

\section{$6 \quad$ Policy implications}

This study makes two methodological advances to improve our understanding of shopping district mode choice. It 1) evaluates variables representing travel time and cost, socioeconomic characteristics, attitudes, perceptions, and local environment characteristics within the same modeling process; and 2) it analyzes shopping mode choice within a tour-based framework. The results reinforce findings from existing research and point to several planning and design strategies to create shopping districts that support walking and transit.

The models showed that short travel times and local population and employment density support walking and taking transit to shopping districts. Therefore, long-term land use plans should encourage redeveloping shopping districts as activity hubs with a higher-density mix of housing, offices, retail, and other activities. In particular, buildings for non-retail uses can be constructed on space currently used for surface parking lots. Higher-density, mixed-use development allows more people to live and work close to shopping opportunities, creating a local environment where walk travel time is competitive with drive time for shopping trips. With higher-density development, high-frequency transit service can serve the core of the activity hub, reducing transit travel time and making it possible for people who live in other parts of the region to access shopping, jobs, and other activities at the hub (Cervero, Ferrell, and Murphy 2002). Similarly, including more retail stores as a part of existing transit-oriented developments can make it possible for people living or working close to a transit hub to do more of their shopping during their daily routine instead of making a special effort on an evening or weekend to drive to a distant mall. Understanding the local potential for these types of land-use changes is critical. These strategies have a greater chance of success in areas where land markets support high development density.

Two variables related to automobile parking (store parking lot size and the cost of driving) were significant in the final model. These variables lend support to previous studies that emphasize parking strategies to increase walking and decrease automobile use (Shoup 1997, Rodriguez et al. 2008). For example, development regulations can be written to set maximum parking limits rather than minimum parking requirements. This helps to reduce off-street automobile parking spaces. Minimizing the land area allocated to automobile parking also makes it possible to cluster buildings more closely together, reducing walking travel time between building entrances. Increasing parking costs can raise the overall cost of driving relative to walking and transit. One strategy to increase these costs is to charge market rates for on-street parking spaces that are currently free or very inexpensive. The local context, particularly existing business vitality and parking demand, is important to consider when evaluating parking strategies. For example, increasing the cost of parking in a struggling shopping district may push customers to other locations. In addition, outreach to local businesses is essential to communicate the potential value of changing parking policies and to decide how to reinvest parking revenues in the shopping district.

The policy strategies highlighted in this section involve improving the convenience and cost of walking and taking transit relative to using an automobile. Improving convenience and cost are important components of a comprehensive approach to shifting routine travel from automobile to more sustainable travel modes. Other aspects of this comprehensive approach include increasing people's awareness of walking and public transit as travel options, improving pedestrian and transit safety (e.g., 
reducing pedestrian crashes) and security (e.g., reducing street crime), and increasing individual and social acceptance of these modes (e.g., strengthening appreciation of physical and mental health benefits, social interaction benefits, and environmental benefits) (Schneider 2013a).

\section{$7 \quad$ Considerations and future research}

Several aspects of the analysis should be revised or expanded in the future. Future analyses should include transit service frequency as an explanatory variable. Transit travel time calculations assumed that survey participants knew the transit schedule, but it may be more realistic to assume that participants did not know the schedule, especially when returning home from the shopping district. If the schedule is unknown, transit service frequency is an important component of transit mode utility. Since transit frequency is often correlated with population and employment density, these density variables could simply be proxies for transit frequency. Even if this is the case, population or employment density are usually a prerequisite for providing transit service to an area, so there may still be an indirect relationship between density and transit mode choice.

Some customers in mixed-use shopping districts may have been employed within the shopping district and traveled to the retail pharmacy before or after work. If a person needed a car at work to have the flexibility to travel to distant meetings, she or he may have driven to and from the shopping district, even if she or he preferred a different mode. In addition, group size was recorded, but the characteristics of the travelers in the group were not captured (e.g., whether or not the respondent was traveling with a child or a senior citizen who needed mobility assistance). This detailed travel information was not collected in order to keep the intercept survey a reasonable length, but it should be investigated in the future.

Several theoretically important variables were tested but did not have a significant relationship with walking, using transit, or driving on shopping district tours. Shopping district design characteristics such as the number of roadway lanes and posted speed limit were not significant, but they should be tested in future studies. Land-use mix was represented indirectly by travel time and the number of other commercial properties near the survey store, but additional measures of mix should be evaluated. Further, while tree canopy coverage was significant in the final model, this attribute should continue to be tested in combination with other types of variables.

In general, variables with high correlations $(\rho>0.5$ or $\rho<-0.5)$ were not included in the same model. However, the moderately correlated transit travel time and transit travel cost variables $(\rho=0.58)$ were included in the same model because of the importance of both time and cost in mode choice decisions. In addition, the distance traveled within the shopping district and total number of stops made on the respondent's tour were also correlated $(\rho=0.77)$. These were included in the same model to capture differences in mode choice between people who traveled to a few stops spread throughout the shopping district versus many stops concentrated in one part of the shopping district.

The model shows significant associations between explanatory variables and the likelihood of walking and using transit for shopping district tours, but this does not imply causation. Additional research should include longitudinal studies that compare communities where a particular strategy has been applied (e.g., increase population and employment density, reduce off-street parking) with control communities. Documenting differences over time using this type of experiment can help quantify how many people in a certain type of community may shift from driving to walking or public transportation after a particular action is implemented. Finally, the survey was conducted in the San Francisco Bay Area, so the method should be repeated in other regions to see if it produces consistent results. 


\section{Acknowledgments}

Special thanks to Carlos Velasquez and Melissa Chinchilla for assisting with the intercept survey distribution and to Robert Cervero, Joan Walker, Elizabeth Deakin, and Elizabeth Macdonald for advising on this study. Fellowship support was provided by the University of California Transportation Center and the U.S. Environmental Protection Agency's (EPA) Science to Achieve Results (STAR) program. Although the research described in the paper has been funded in part by the STAR program through grant (FP-91695101-0), it has not been subjected to any EPA review and therefore does not necessarily reflect the views of the agency, and no official endorsement should be inferred.

\section{References}

Besser, L., and A. Dannenberg. 2005. Walking to public transit: Steps to help meet physical activity recommendations. American Journal of Preventive Medicine 29: 273-280.

Bhat, C.R. and R. Gossen. 2004. A mixed multinomial logit model analysis of weekend recreational episode type choice. Transportation Research Part B 38: 767-787.

Black, C., A. Collins, and M. Snell. 2001. Encouraging walking: The case of journey-to-school trips in compact urban areas. Urban Studies 38: 1121-1141.

Bowman J. L., and M. E. Ben-Akiva. 2000. Activity-based disaggregate travel demand model system with activity schedules. Transportation Research Part A 35: 1-28.

Cantwell, M., B. Caulfield, and M. O'Mahony. 2009. Examining the factors that impact public transport commuting satisfaction. Journal of Public Transportation 12(2): 1-21.

Cao, X., P. L. Mokhtarian, and S. L. Handy. 2009. Examining the impacts of residential self-selection on travel behavior: A focus on empirical findings. Transport Reviews 29(3) 359-395.

Cervero, R., and M. Duncan. 2003. Walking, bicycling, and urban landscapes: Evidence from the San Francisco Bay Area. American Journal of Public Health 93(9) 1478-1483.

Cervero, R., C. Ferrell, and S. Murphy. 2002. Transit-Oriented Development and Joint Development in the United States: A Literature Review. Washington, DC: Transit Cooperative Research Program, Transportation Research Board.

Chatman, D. G. 2009. Residential choice, the built environment, and nonwork travel: Evidence using new data and methods. Environment and Planning A 4: 1072-1089.

Chen, C., H. Gong, and R. Paaswell. 2008. Role of the built environment on mode choice decisions: Additional evidence on the impact of density. Transportation 35: 285-299.

Eboli L., and G. Mazzulla. 2008. A stated preference experiment for measuring service quality in public transport. Transportation Planning and Technology 31(5): 509־-523.

Evans, J. E. 2004. Chapter 9: Transit scheduling and frequency. TCRP Report 95: Traveler Response to Transportation System Changes. Washington, DC: Transit Cooperative Research Program, Transportation Research Board.

Ewing R., and R. Cervero. 2010. Travel and the built environment: A meta-analysis. Journal of the American Planning Association 76(3) 1-30.

Federal Highway Administration. 2009. National Household Travel Survey. Washington, DC: FHWA.

Frank, L., M. Bradley, S. Kavage, J. Chapman, and T. K. Lawton. 2008. Urban form, travel time, and cost relationships with tour complexity and mode choice. Transportation 35(1) 37-54.

Handy, S. L., X. Cao, P. L. Mokhtarian. 2005. Correlation or causality between the built environment and travel behavior? Evidence from Northern California. Transportation Research Part D 10(6) 427-444.

Hensher, D.A. and A.J. Reyes. 2000. Trip chaining as a barrier to the propensity to use public transport. 
Transportation 27: 341-361.

Jonnalagadda, N., J. Freedman, W. A. Davidson, and J. D. Hunt. 2001. Development of microsimulation activity-based model for San Francisco: Destination and mode choice models. Transportation Research Record 1777: 25-35.

Kim, S., and G. F. Ulfarsson. 2008. Curbing automobile use for sustainable transportation: Analysis of mode choice on short home-based trips. Transportation 35: 723-737.

Kitamura, R., P. Mokhtarian, and L. Laidet. 1997. A micro-analysis of land use and travel in five neighborhoods in the San Francisco Bay Area. Transportation 24: 125-158.

Krizek, K. 2003. Neighborhood services, trip purpose, and tour-based travel. Transportation 30: 387410.

Krizek, K., A. Forsyth, and L. Baum. 2009. Walking and Cycling International Literature Review. Melbourne, Australia: Department of Transport.

Litman T. and D. Burwell. 2006. Issues in sustainable transportation. International Journal of Global Environmental Issues 6(4): 331-347.

Long, L., J. Lin, and K. Proussaloglou. 2010. Investigating contextual variability in mode choice in Chicago using a hierarchical mixed logit model. Urban Studies 47(11) 2445־-2459.

Mackett, R. L. 2003. Why do people use their cars for short trips? Transportation 30: 329-349.

Manaugh, K. and A. M. El-Geneidy. 2013. Does distance matter? Exploring the links among values, motivations, home location, and satisfaction in walking trips. Transportation Research Part A 50: 198-208.

Pratt, R. H., and Evans, J. E. 2004. Chapter 10: Bus routing and coverage. TCRP Report 95: Traveler Response to Transportation System Changes. Washington, DC: Transit Cooperative Research Program, Transportation Research Board.

Purvis, C. 1997. Travel Demand Models for the San Francisco Bay Area (BAYCAST-90): Technical Summary. Oakland, CA: Metropolitan Transportation Commission.

Redman, L., M. Friman, T. Gärling, and T. Hartig. 2013. Quality attributes of public transport that attract car users: A research review. Transport Policy 25: 119-127.

Rodriguez, D. A., S. Aytur, A. Forsyth, J. M. Oakes, and K. J. Clifton. 2008. Relation of modifiable neighborhood attributes to walking. Preventive Medicine 47: 260-264.

Rubin, J. 2011. Choosing transit: The influence of past travel behavior, attitudes and habits on present choices, doctorate dissertation. Berkeley, CA: University of California.

Ryley, T. J. 2008. The propensity for motorists to walk for short trips: Evidence from West Edinburgh. Transportation Research Part A 42: 620-628.

Saelens, B. E., J. F. Sallis, J. B. Black, and D. Chen. 2003. Neighborhood-based differences in physical activity: An environment scale evaluation. American Journal of Public Health 93(9) 1552-1558.

Schneider R. J., L .S. Arnold, and D. R. Ragland. 2009. A pilot model for estimating pedestrian intersection crossing volumes, Transportation Research Record 2140: 13-26.

Schneider, R. J. 2011. Understanding Sustainable Transportation Choices: Shifting Routine Automobile Travel to Walking and Bicycling. http://www.uctc.net/research/UCTC-DISS-2011-01.pdf.

Schneider, R. J., T. Henry, M. F. Mitman, L. Stonehill, and J. Koehler. 2012. Development and application of the San Francisco pedestrian intersection volume model. Transportation Research Record 2299: 65-78.

Schneider, R. J. 2013a. Theory of routine mode choice decisions: An operational framework to increase sustainable transportation. Transport Policy 25: 128-137.

Schneider, R. J. 2013b. Measuring transportation at a human scale: An intercept survey approach to capture pedestrian activity. Journal of Transport and Land Use 6(3): 43-59. 
Shoup, D. C. 1997. The high cost of free parking. Journal of Planning Education and Research 17: 3-20. Steiner, R. 1998. Trip generation and parking requirements in traditional shopping districts. Transportation Research Record 1617: 28-37.

Suminski, R. R., W. S. Poston, R. L. Petosa, E. Stevens, and L. M. Katzenmoyer. 2005. Features of the neighborhood environment and walking by U.S. adults. American Journal of Preventative Medicine 28: 149-155.

Too, L., and G. Earl. 2010. Public transport service quality and sustainable development: A community stakeholder perspective. Sustainable Development 18: 51-61

Train, K. 2009. Discrete Choice Methods with Simulation, Second Edition. Cambridge, UK: Cambridge University Press.

Vaca, E. and J. R. Kuzmyak. 2005. Chapter 13: Parking pricing and fees. TCRP Report 95: Traveler Response to Transportation System Changes. Washington DC: Transit Cooperative Research Program, Transportation Research Board.

Viton, P. A. 2004. Will mixed logit change urban transport policies? Journal of Transport Economics and Policy 38(3): 403-423.

Wasfi, R., N. Ross, and A. El-Geneidy. 2013. Achieving recommended daily physical activity levels through commuting by public transportation: Unpacking individual and contextual influences. Health and Place 23: 18-25. 


\section{Appendix A: Explanatory variables considered for statistical models}

Table A-1: Travel and socioeconomic variables

\begin{tabular}{|c|c|c|c|c|c|c|}
\hline \multicolumn{2}{|r|}{ Travel Variables } & \multicolumn{5}{|c|}{ Summary Statistics $^{1}$} \\
\hline Variable Name & Description & $\mathbf{n}$ & Mean & \begin{tabular}{|l|} 
Std. Dev. \\
\end{tabular} & Min. & Max. \\
\hline Auto Distance & Estimated travel distance by automobile $(\mathrm{km})^{2}$ & 388 & 6.130 & 13.215 & 0.322 & 132.743 \\
\hline Auto Time & Estimated travel time by automobile (minutes) ${ }^{3}$ & 388 & 11.728 & 12.555 & 3.500 & 127.000 \\
\hline Auto Cost & Estimated total automobile cost (dollars) ${ }^{4}$ & 388 & 2.728 & 6.435 & 0.027 & 93.775 \\
\hline Transit Time & Estimated travel time by transit (minutes) $)^{5}$ & 266 & 39.026 & 35.427 & 6.000 & 299.000 \\
\hline Transit Cost & Estimated cost by transit (dollars) ${ }^{6}$ & 266 & 3.240 & 3.136 & 0.000 & 40.000 \\
\hline Walk Distance & Estimated travel distance by walking $(\mathrm{km})^{7}$ & 387 & 5.525 & 12.203 & 0.322 & 123.893 \\
\hline Walk Time & Estimated travel time by walking (minutes) ${ }^{8}$ & 387 & 64.473 & 143.939 & 2.000 & 1534.000 \\
\hline Home to Store Distance & Straight-line distance between home and survey store $(\mathrm{km})$ & 388 & 2.245 & 4.711 & 0.063 & 45.733 \\
\hline Total Tour Distance & Actual tour distance in miles $(\mathrm{km})$ & 388 & 6.272 & 12.862 & 0.364 & 148.958 \\
\hline Total Tour Distance $<2 \mathrm{mi}$. & Actual tour distance less than $2 \mathrm{mi} .(3.2 \mathrm{~km})(1=$ Yes, $0=\mathrm{No})$ & 388 & 0.575 & 0.495 & 0.000 & 1.000 \\
\hline Number of Stops & Total tour stops (including returning home) & 388 & 3.320 & 1.402 & 2.000 & 11.000 \\
\hline Miles in Shopping District & Travel distance between first and last stop in shopping district $(\mathrm{km})$ & 388 & 0.420 & 0.513 & 0.000 & 2.782 \\
\hline Miles Per Stop in District & Distance per stop within shopping district $(\mathrm{km})$ & 388 & 0.137 & 0.148 & 0.000 & 0.756 \\
\hline Single-Stop Tour & Tour was to store and back home $(1=$ Yes, $0=\mathrm{No})$ & 388 & 0.314 & 0.465 & 0.000 & 1.000 \\
\hline No Bags & Carrying 0 bags $(1=$ Yes, $0=$ No $)$ & 388 & 0.168 & 0.374 & 0.000 & 1.000 \\
\hline 2+ Bags & Carrying 2 or more bags $(1=$ Yes, $0=\mathrm{No})$ & 388 & 0.253 & 0.435 & 0.000 & 1.000 \\
\hline Shopping Alone & Shopping alone (group size $=1)(1=$ Yes, $0=\mathrm{No})$ & 385 & 0.743 & 0.438 & 0.000 & 1.000 \\
\hline Cool Temperature & Temperature $<60^{\circ} \mathrm{F}\left(<16^{\circ} \mathrm{C}\right)(1=$ Yes, $0=\mathrm{No})$ & 388 & 0.064 & 0.246 & 0.000 & 1.000 \\
\hline Saturday & Survey was on Saturday $(1=$ Yes, $0=$ No) & 388 & 0.518 & 0.500 & 0.000 & 1.000 \\
\hline \multicolumn{2}{|r|}{ Respondent Socioeconomic Variables } & \multicolumn{5}{|c|}{ Summary Statistics ${ }^{1}$} \\
\hline Variable Name & Description & $\mathbf{n}$ & Mean & \begin{tabular}{|l|} 
Std. Dev. \\
\end{tabular} & Min. & Max. \\
\hline Female & Female $(1=$ Yes, $0=$ No $)$ & 388 & 0.559 & 0.497 & 0.000 & 1.000 \\
\hline Spanish Speaker & Survey completed in Spanish $(1=$ Yes, $0=$ No $)$ & 388 & 0.101 & 0.301 & 0.000 & 1.000 \\
\hline Young Adult & Young adult (age 18 to 34$)(1=$ Yes, $0=\mathrm{No})$ & 388 & 0.320 & 0.467 & 0.000 & 1.000 \\
\hline Middle-Aged Adult & Middle-aged adult (age 35-64) $(1=$ Yes, $0=$ No) & 388 & 0.513 & 0.500 & 0.000 & 1.000 \\
\hline Senior Citizen & Senior citizen (over age 64$)(1=$ Yes, $0=\mathrm{No})$ & 388 & 0.168 & 0.374 & 0.000 & 1.000 \\
\hline Employed & Employed (includes employed students) $(1=$ Yes, $0=\mathrm{No})$ & 387 & 0.545 & 0.499 & 0.000 & 1.000 \\
\hline Unemployed & Unemployed $(1=$ Yes, $0=$ No $)$ & 387 & 0.209 & 0.407 & 0.000 & 1.000 \\
\hline Student & Student (includes employed students) $(1=$ Yes, $0=\mathrm{No})$ & 387 & 0.111 & 0.315 & 0.000 & 1.000 \\
\hline Retired & Retired $(1=$ Yes, $0=$ No) & 387 & 0.150 & 0.357 & 0.000 & 1.000 \\
\hline Homemaker & Homemaker $(1=$ Yes, $0=$ No $)$ & 387 & 0.021 & 0.142 & 0.000 & 1.000 \\
\hline No-Child Household & Household with 0 children $(1=$ Yes, $0=$ No $)$ & 388 & 0.639 & 0.481 & 0.000 & 1.000 \\
\hline Single Adult & Household with a single adult $(1=$ Yes, $0=\mathrm{No})$ & 388 & 0.255 & 0.437 & 0.000 & 1.000 \\
\hline Group House & Household with 4 or more adults $(1=$ Yes, $0=$ No) & 388 & 0.129 & 0.335 & 0.000 & 1.000 \\
\hline Lower Income & Household income less than $\$ 50,000$ per year $(1=$ Yes, $0=$ No $)$ & 347 & 0.542 & 0.499 & 0.000 & 1.000 \\
\hline Higher Income & Household income more than $\$ 100,000$ per year $(1=$ Yes, $0=$ No $)$ & 347 & 0.205 & 0.404 & 0.000 & 1.000 \\
\hline Bus Pass & Owns a monthly or annual bus pass $(1=$ Yes, $0=\mathrm{No})$ & 384 & 0.193 & 0.395 & 0.000 & 1.000 \\
\hline Disability & Has a disability (self-reported) $(1=$ Yes, $0=\mathrm{No})$ & 388 & 0.147 & 0.354 & 0.000 & 1.000 \\
\hline No-Car Household & 0 motor vehicles in household $(1=$ Yes, $0=\mathrm{No})$ & 387 & 0.191 & 0.394 & 0.000 & 1.000 \\
\hline Multi-Car Household & 2 or more motor vehicles in household ( $1=$ Yes, $0=$ No) & 387 & 0.491 & 0.501 & 0.000 & 1.000 \\
\hline Number of Bicycles & Number of bicycles in household & 388 & 1.585 & 2.542 & 0.000 & 30.000 \\
\hline
\end{tabular}


Table A-2: Attitude and perception and shopping district variables

\begin{tabular}{|c|c|c|c|c|c|c|}
\hline \multicolumn{2}{|c|}{ Respondent Attitude and Perception Variables } & \multicolumn{5}{|c|}{ Summary Statistics ${ }^{1}$} \\
\hline Variable & Description & $\mathbf{n}$ & Mean & Std. Dev. & Min. & Max. \\
\hline Enjoy Walking & Respondent enjoys walking $(1=\text { Yes, } 0=\mathrm{No})^{9}$ & 388 & 0.892 & 0.311 & 0.000 & 1.000 \\
\hline General Walk Crash Risk & $\begin{array}{l}\text { Perceive walking to be risky (in general) } \\
(1=\text { Yes, } 0=\mathrm{No})^{9}\end{array}$ & 388 & 0.291 & 0.455 & 0.000 & 1.000 \\
\hline Negative Walk Culture & $\begin{array}{l}\text { People in neighborhood have negative view of walking } \\
(1=\text { Yes, } 0=\mathrm{No})^{9}\end{array}$ & 371 & 0.127 & 0.333 & 0.000 & 1.000 \\
\hline Neighborhood Walk Crime Risk & $\begin{array}{l}\text { Perceive high crime risk if walking in shopping district } \\
\text { during day }(1=\text { Yes, } 0=\mathrm{No})^{9}\end{array}$ & 386 & 0.106 & 0.309 & 0.000 & 1.000 \\
\hline Neighborhood Walk Crash Risk & $\begin{array}{l}\text { Perceive high crash risk if walking in shopping district } \\
\text { during day }(1=\text { Yes, } 0=\mathrm{No})^{9}\end{array}$ & 383 & 0.138 & 0.346 & 0.000 & 1.000 \\
\hline \multicolumn{2}{|c|}{ Shopping District Variables } & \multicolumn{5}{|c|}{ Summary Statistics ${ }^{1}$} \\
\hline Variable & Description & $\mathbf{q}$ & Mean & Std. Dev. & Min. & Max. \\
\hline Urban Core & Urban core shopping district $(1=$ Yes, $0=\mathrm{No})$ & 20 & 0.150 & 0.366 & 0.000 & 1.000 \\
\hline Suburban Main Street & $\begin{array}{l}\text { Suburban main street shopping district } \\
(1=\text { Yes, } 0=\mathrm{No})\end{array}$ & 20 & 0.400 & 0.503 & 0.000 & 1.000 \\
\hline Suburban Thoroughfare & $\begin{array}{l}\text { Suburban thoroughfare shopping district } \\
(1=\text { Yes, } 0=\mathrm{No})\end{array}$ & 20 & 0.350 & 0.489 & 0.000 & 1.000 \\
\hline Suburban Shopping Complex & $\begin{array}{l}\text { Suburban shopping complex shopping district } \\
(1=\text { Yes, } 0=\mathrm{No})\end{array}$ & 20 & 0.100 & 0.308 & 0.000 & 1.000 \\
\hline Population Density & $\begin{array}{l}\text { Total population living within } 0.1 \mathrm{mi} .(161 \mathrm{~m}) \text { of } \\
\text { store }(00 \mathrm{~s})^{10}\end{array}$ & 20 & 357 & 286 & 57 & 1223 \\
\hline Employment Density & Total number of jobs within $0.5 \mathrm{mi} .(804 \mathrm{~m})(000 \mathrm{~s})$ & 20 & 11192 & 31757 & 195 & 145200 \\
\hline Commercial Density & $\begin{array}{l}\text { Total number of commercial properties within } \\
0.25 \mathrm{mi} .(402 \mathrm{~m})^{11}\end{array}$ & 20 & 55.800 & 62.757 & 6.000 & 272.000 \\
\hline Median Income & $\begin{array}{l}\text { Median annual household income within } 0.5 \mathrm{mi} . \\
(804 \mathrm{~m})(\$)\end{array}$ & 20 & 59042 & 20336 & 28243 & 93413 \\
\hline Percent White & $\begin{array}{l}\text { Proportion of population living within } 0.5 \mathrm{mi} . \\
(804 \mathrm{~m}) \text { that is White }\end{array}$ & 20 & 0.517 & 0.246 & 0.101 & 0.898 \\
\hline Sidewalk Coverage & Proportion sidewalk coverage on multilane roadways ${ }^{12}$ & 20 & 0.900 & 0.122 & 0.536 & 1.000 \\
\hline Slope & Average percent slope along multilane roadways ${ }^{13}$ & 20 & 2.826 & 4.763 & 0.622 & 22.093 \\
\hline Intersection Density & Number of street intersections within $0.5 \mathrm{mi} .(804 \mathrm{~m})$ & 20 & 114.250 & 31.754 & 56.000 & 174.000 \\
\hline Tree Canopy Coverage & $\begin{array}{l}\text { Estimated \% of street ROW covered by tree canopy } \\
\text { within } 0.5 \mathrm{mi} .(804 \mathrm{~m})^{15}\end{array}$ & 20 & 7.500 & 4.617 & 1.000 & 15.000 \\
\hline Road Width & Adjacent roadway curb-to-curb width $(\mathrm{m})^{16}$ & 20 & 22.525 & 5.690 & 11.583 & 32.501 \\
\hline Road Street Parking & On-street parking coverage on adjacent roadway ${ }^{16,17}$ & 20 & 0.573 & 0.405 & 0.000 & 1.000 \\
\hline Road Lanes & Average adjacent roadway number of travel lanes ${ }^{16,18}$ & 20 & 4.042 & 1.115 & 2.000 & 5.997 \\
\hline Road AADT & Traffic volume (AADT) on roadway adjacent to store & 20 & 23316 & 10320 & 9771 & 50500 \\
\hline Road Speed Limit & $\begin{array}{l}\text { Average posted speed limit along adjacent roadway } \\
(\mathrm{MPH})^{16}\end{array}$ & 20 & 30.000 & 5.065 & 25.000 & 37.500 \\
\hline Road Setback & $\begin{array}{l}\text { Average building setback along adjacent roadway } \\
(\mathrm{m})^{16,19}\end{array}$ & 20 & 9.021 & 8.685 & 0.000 & 25.709 \\
\hline Street Crossing Distance & Average pedestrian crossing distance $(\mathrm{m})^{16,20}$ & 20 & 21.931 & 6.318 & 12.543 & 35.662 \\
\hline Store Square Meters & Gross area of store building (square meters) & 20 & 1251 & 484 & 493 & 2338 \\
\hline Drive-Through Window & Store has a drive-through window $(1=$ Yes, $0=$ No $)$ & 20 & 0.300 & 0.470 & 0.000 & 1.000 \\
\hline Store Parking Spaces & $\begin{array}{l}\text { Spaces in the store parking lot (includes shared } \\
\text { parking) }(00 \mathrm{~s})\end{array}$ & 20 & 129.500 & 142.136 & 0.000 & 442.000 \\
\hline Pay Parking on Road & $\begin{array}{l}\text { Presence of pay parking within } 0.1 \mathrm{mi} .(161 \mathrm{~m}) \\
(1=\text { Yes, } 0=\mathrm{No})^{21}\end{array}$ & 20 & 0.450 & 0.510 & 0.000 & 1.000 \\
\hline Median Parking Price & $\begin{array}{l}\text { Median weekday mid-day on-street parking pricel } \\
\text { hour within } 0.1 \mathrm{mi} .(161 \mathrm{~m})(\$)\end{array}$ & 20 & 0.550 & 0.999 & 0.000 & 3.500 \\
\hline Setback Distance & Distance from store door to public sidewalk $(\mathrm{m})^{22}$ & 20 & 18.300 & 23.202 & 1.000 & 90.000 \\
\hline Distance to Train Station & Distance from store to closest train station $(\mathrm{km})^{23}$ & 20 & 2.188 & 3.603 & 0.141 & 12.781 \\
\hline
\end{tabular}




\section{Footnotes}

1) Non-responses were removed. This is reflected in the sample size for each variable.

2) Tour distance by automobile represents the estimated distance that the customer would need to travel by automobile from home to the first stop in the shopping district and from the last stop in the shopping district to return home. It represents the shortest-time route selected by Google Maps directions.

3) Tour travel time by automobile represents the estimated total time that the customer would need to travel by automobile from home to the first stop in the shopping district and from the last stop in the shopping district to return home. Assumptions used to calculate respondent travel times are provided in Schneider (2011).

4) The total auto cost represents the sum of the expected out-of-pocket gas, parking, toll, and/or taxi costs paid by a respondent driving to the shopping district. Assumptions used to calculate respondent travel costs are provided in Schneider (2011).

5) Tour travel time by public transit represents the total time that the customer would need to travel by transit from home to the first stop in the shopping district and from the last stop in the shopping district to return home. Transit time calculations assumed that survey participants knew the transit schedule and would have to wait two minutes before the bus or train arrived. Other assumptions used to calculate respondent travel times are provided in Schneider (2011).

6) Tour travel cost by public transit represents the total out-of-pocket fare that the customer would need to travel by transit from home to the first stop in the shopping district and from the last stop in the shopping district to return home (unless the customer has a pre-paid transit pass). Assumptions used to calculate respondent travel costs are provided in Appendix $\mathrm{K}$ of Schneider (2011).

7) Tour distance by walking represents the distance that the customer would need to travel by walking from home to the first stop in the shopping district and from the last stop in the shopping district to return home. It represents the shortest time route selected by Google Maps directions.

8) Tour travel time by walking represents the total time that the customer would need to travel by walking from home to the first stop in the shopping district and from the last stop in the shopping district to return home. Assumptions used to calculate respondent travel times are provided in Schneider (2011).

9) Agreement with the statement included two of the five categories on a five-point Likert scale (i.e., "Agree" or "Strongly Agree").

10) Total population within 0.1 miles (161 meters) is calculated from 2000 Census block group data. The calculation of population only included portions of Census block groups within the 0.1-mile (161-meter) radius of the store.

11) Commercial retail/entertainment properties are defined by the four county assessor's offices. These commercial land uses include commercial, entertainment, store, service, tourism, store on first floor with other above, department store, single-story store, restaurant, post office, bank, supermarket, food store, lodge hall, car wash, gas station, auto dealer, movie theater, bowling alley, winery, stadium, commercial mix, and commercial building. This category does not include commercial office buildings. Note that one building structure could include multiple commercial properties.

12) Sidewalk coverage is calculated on multilane roadways within 0.5 mile (804 meters) of the store. The calculation assumes that complete coverage is continuous sidewalks on both sides of the street. Therefore, if a street has sidewalks on both sides, it has 100 percent sidewalk coverage. If a street has a complete sidewalk on one side, but no sidewalk on the other, it has 50 percent coverage.

13) Percent slope is calculated on multilane roadways within 0.5 miles (804 meters) of the store. It is calculated as the change in elevation between the two segment endpoints (intersections) divided by the length of the street segment.

14) Bicycle facilities include bicycle lanes, shared lane markings, bicycle boulevards, and multi-use trails. They do not include streets that only have bicycle route signs. Bicycle facility miles were calculated using the same methodology as automobile lane miles. If bicycle lanes or shared lane markings are on both sides of a 1-kilometer-long street segment, this represents two kilometers of bicycle facilities (this avoids the problem of misrepresenting one-way bicycle facilities on one-way streets). Bicycle boulevards and multi-use trails are two-way facilities, so one-kilometer of centerline counts as two kilometers of bicycle facilities. 
15) Average percent tree coverage is an average of the percent tree coverage on each multilane street segment within 0.5 miles (804 meters) of the store. Tree coverage is an estimate of the total public right-of-way surface area (edge-of-sidewalk to edge-ofsidewalk) covered by tree canopy. This was estimated from aerial photographs.

16) Adjacent roadway variables are measured within a 0.5-mile (804 meter) corridor ( 0.25 miles or 402 meters in either direction) along the commercial roadway adjacent to the store. Speed limit is posted in miles per hour (mph), so it is reported using this measure. Note that $10 \mathrm{mph}=16.1 \mathrm{kph}$.

17) A block is considered to have on-street parking if on-street parking is legal (i.e., parked cars do not need to be present). Each side of the street is considered separately (e.g., on-street parking on both sides $=100$ percent coverage; on-street parking on one side $=50$ percent coverage).

18) Travel lanes include all general-purpose through-lanes in both directions. The number of through-lanes does not include left- or right-turn lanes, two-way center-turn lanes, bicycle lanes, shoulders, or other auxiliary lanes. In addition, it does not include lanes that end within the segment.

19) Average setback is a rough estimate of the average distance between the sidewalk or roadway edge and the front of each building. If a road segment does not have buildings (e.g., overpass, underpass, etc.), it is not considered in the average setback measurement.

20) Street crossing distance represents the average width of the mainline commercial roadway at each pedestrian crossing location.

21) Presence of pay parking within 0.1 miles (161 meters) was noted using Google street view.

22) Distance from store door to public sidewalk was measured as the most direct path from the door to the sidewalk that did not involve crossing fences or landscaping. Measurement was done using the Google Earth measuring tool. Building doors were located using Google street view.

23) Distance from the store to the closest Bay Area Rapid Transit or other heavy rail train station was measured as the straightline distance from the store centroid to the train station centroid. Measurement was done in GIS. 